\title{
Session 2549 \\ Developing Student Awareness in the Social and Economic Aspects of Civil Engineering Projects
}

\author{
Andrew T. Rose \\ University of Pittsburgh at Johnstown
}

\begin{abstract}
Through the use of a video, a writing assignment, and class discussions, students in a junior level engineering technology course were exposed to and asked to consider and discuss some of social and economic issues associated with various projects. A survey prior to these experiences was used to assess student awareness of the social an economic aspects of civil engineering projects in general and a highway by-pass and large dam in particular. Students then watched a video on large dams and were assigned to write about the social and economic issues associated with large dams. In addition they were asked to discuss the social and economic issues of a local project of their choice. After the assignment, class discussion was used to highlight some of the social and economic issues encountered in each project. Student feedback on this learning experience was also obtained.
\end{abstract}

\section{Introduction}

Civil engineering technology students prepare for technical careers in a profession in which the social and economic implications of a project are often as important as the technical aspects. As such, their education should not only include learning the technical aspects of their discipline, but also should provide opportunities to develop a sense of awareness regarding the social and economic implications of a variety of civil engineering projects. $\mathrm{ABET}^{1}$ recognizes this need and requires engineering technology programs to include such issues in the curriculum.

Professional issues can be incorporated into the engineering technology curriculum. One example would be to include social and economic impacts as part of new or revised courses dealing with sustainable development. ${ }^{2}$ Another possibility exists in programs offering courses utilizing servicelearning with community-based design projects. ${ }^{3}$ To fully realize the benefits of service-learning, a structured reflection component should be used to consider the social impacts of technology. ${ }^{3}$ In one engineering technology program, ${ }^{4}$ a required course in Designing for the Environment has been proposed to better address this need. At one institution, economic, social and cultural impacts have been incorporated into a web-based Environmental Impact Assessment course. ${ }^{5}$ Lower level courses that teach engineering design concepts ${ }^{6}$ or introduction to engineering courses $^{7}$ often include some discussion of social and economic issues.

Incorporating professional issues such as the social and economic impact of engineering projects into the curriculum is best accomplished throughout the undergraduate curriculum. ${ }^{3}$ Instructors must take opportunities to include these within discipline specific courses where the relation between the technical aspects taught in class and real world applications will be most apparent for

Proceedings of the 2003 American Society for Engineering Education Annual

Conference \& Exposition Copyright (C) 2003, American Society for Engineering 
students. Repeated exposure to such issues helps reinforce students' understanding of why consideration of the social and economic impacts of engineering projects is important.

When discussing how civil engineering projects affect society and the economy, students often focus more easily on the social and economic benefits of civil engineering projects. They envision how a dam forming a new water supply reservoir, improved water and wastewater treatment, or new highways improve the potential of an area for economic development. They see how developing a site and constructing a new school or hospital may improve the quality of life in a municipality. What they may fail to see is the detrimental effects of such projects. The negative impact on the natural environment resulting from a dam or large development project, the economic failure of main street businesses after by-passing a small town with a new highway, the effect of different highway alignments or bridge locations on a community, or the decline of inner city economies resulting from suburban development are examples that students may not easily see, but may be significant issues for projects they will encounter during their careers. Developing an appreciation of such issues should be an important aspect of their engineering technology education.

\section{Students Involved}

The students involved were juniors in a B.S. degree program in Civil Engineering Technology (CET). The course was Soil Engineering, a four-credit course that includes a laboratory. The course is designated as "writing enhanced" by the University indicating that $25 \%$ of the course grade is based on writing assignments. In addition, feedback and opportunities for revision are provided by a student peer-review process. ${ }^{8}$ There were 25 students in the class.

\section{Initial Assessment Survey}

Prior to asking students to consider the social and economic effects of typical civil engineering projects, students completed a brief survey to assess their awareness of the importance of these issues in civil engineering projects. A copy of the survey is included in Appendix A. The results of the survey are summarized in Table 1.

Table 1. Summary of Initial Assessment Survey

\begin{tabular}{|l|c|}
\hline \multicolumn{1}{|c|}{ Issue Students Considered } & Average Student Response \\
\hline $\begin{array}{l}\text { I feel I am generally aware of the impacts civil } \\
\text { engineering projects have on society and the } \\
\text { economy }\end{array}$ & 1.68 \\
(1 Agree - 5 Disagree) & \\
\hline $\begin{array}{l}\text { Most large civil engineering projects have little } \\
\text { to no impact on society or a community } \\
\text { (1 Agree - 5 Disagree) }\end{array}$ & 4.84 \\
\hline $\begin{array}{l}\text { Most large civil engineering projects have little } \\
\text { to no impact on the economy beyond those } \\
\text { employed in design and construction } \\
\text { (1 Agree - 5 Disagree) }\end{array}$ & 4.52 \\
\hline
\end{tabular}

As can be seen in this table, students generally feel that they are aware of the impacts civil engineering projects have on society and the economy. They also strongly believe large projects 
have an impact on society. They also believe that large projects do have an impact on the economy beyond those employed in design and construction. The strong response of students indicating a high level of awareness and understanding of these issues suggests that students have developed some sense of awareness by their junior year.

Follow up questions had students consider a large dam project and a highway by-pass project and list the positive and negative impacts such projects would have on the economy and social landscape of a local community. Table 2 summarizes the most common responses provided.

Table 2. Summary of Student Response Discussing Impact of Selected Projects

\begin{tabular}{|c|c|}
\hline \multicolumn{2}{|c|}{$\begin{array}{l}\text { A large dam is to be constructed in rural area of a developing nation to create a large lake } \\
\text { to provide water for irrigation and for generating electricity }\end{array}$} \\
\hline Question & Student Responses \\
\hline $\begin{array}{l}\text { How do you think such a dam would help the } \\
\text { developing nation's economy? }\end{array}$ & $\begin{array}{ll}\text { - } & \text { Supply energy } \\
\text { - } & \text { Create jobs } \\
\text { - } & \text { Supply water for agriculture } \\
\text { - } & \text { Benefits power companies } \\
\text { - } & \text { Opportunity for growth } \\
\text { - } & \text { Tourism benefiting the economy } \\
\text { - } & \text { Could be a national landmark } \\
\end{array}$ \\
\hline How might such a project hurt the economy? & $\begin{array}{l}\text { - } \\
\text { - } \text { Fo impact (5) } \\
\text { - } \text { May have to raise taxes to build it } \\
\text { - } \text { Catastrophe if it fails } \\
\text { - } \text { May elimininate local jobs } \\
\text { - } \text { Destroys natural resources } \\
\text { - } \text { Affects fish migration } \\
\text { - } \quad \text { May nenefit few if privately owned } \\
\text { - Costs for maintenance }\end{array}$ \\
\hline $\begin{array}{l}\text { How do you think building this large project } \\
\text { would benefit the social landscape of the } \\
\text { developing nation? }\end{array}$ & $\begin{array}{l}\text { - National pride } \\
\text { - } \text { Appear as a more advanced society } \\
\text { - } \quad \text { Ning respect to nation } \\
\text { - } \text { Better economy = happier people } \\
\text { - Tourism and recreational aspects } \\
\text { - } \quad \text { Provides need for educated people } \\
\text { - } \quad \text { More people will move to cities supplied water \& electricity } \\
\text { - } \quad \text { Lower cost electricity spurs development } \\
\text { - Variety of jobs created }\end{array}$ \\
\hline
\end{tabular}




\begin{tabular}{|c|c|}
\hline $\begin{array}{l}\text { How do you think building this large project } \\
\text { would (could) hurt the social landscape of the } \\
\text { developing nation? }\end{array}$ & 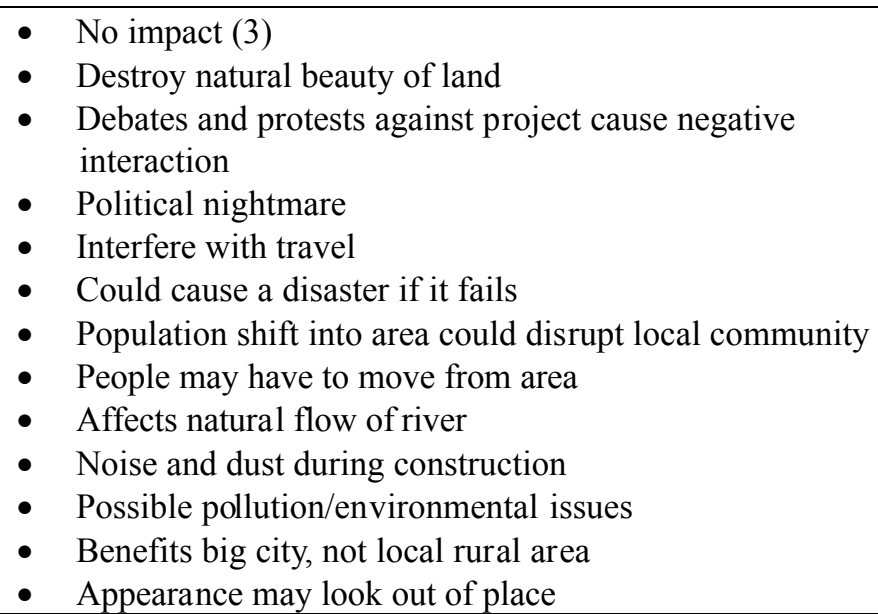 \\
\hline
\end{tabular}


Table 2. Summary of Student Response Discussing Impact of Selected Projects (continued)

\begin{tabular}{|c|c|}
\hline \multicolumn{2}{|c|}{ A highway bypass project is proposed around a community in western Pennsylvania } \\
\hline Question & Student Responses \\
\hline $\begin{array}{l}\text { How do you think a highway bypass project } \\
\text { would help the local economy? }\end{array}$ & $\begin{array}{l}\text { - } \text { Decrease traffic congestion } \\
\text { - } \quad \text { Decrease noise } \\
\text { - } \quad \text { Cess pollution } \\
\text { - } \text { Provide easier access to area } \\
\text { - Jobs created to serve drivers' needs } \\
\text { - } \quad \text { More people may move to area because of easy access } \\
\text { - } \quad \text { Promotes community expansion } \\
\text { - Helps local employment short term } \\
\text { - Faster access to other areas } \\
\text { - } \quad \text { More traffic }=\text { more business } \\
\text { - } \quad \text { Elimity to move goods quicker through area } \\
\end{array}$ \\
\hline $\begin{array}{l}\text { How do you think a highway bypass project } \\
\text { would hurt the local economy? }\end{array}$ & $\begin{array}{l}\text { - } \\
\text { - } \\
\text { - } \\
\text { - }\end{array}$ \\
\hline $\begin{array}{l}\text { How do you think a highway bypass project } \\
\text { would benefit the social landscape in the } \\
\text { community? }\end{array}$ & $\begin{array}{l}\text { - } \\
\text { - } \quad \text { Make to travel to town without all the traffic } \\
\text { - } \quad \text { Less traffic in town will make people feel safer, make area } \\
\text { more desirable } \\
\text { - If done properly it can highlight a community } \\
\text { - } \text { Increased accessibility = community population could grow } \\
\text { - } \text { malls and stores } \\
\text { - } \text { Keeps visitors/strangers out of community } \\
\text { - } \text { Less traffic on local roads is desirable } \\
\text { - Greater highway access for the community may increase } \\
\text { - } \text { population diversity } \\
\end{array}$ \\
\hline
\end{tabular}

Proceedings of the 2003 American Society for Engineering Education Annual Conference \& Exposition Copyright $\odot$ 2003, American Society for Engineering Education 
Table 2. Summary of Student Response Discussing Impact of Selected Projects (continued)

\begin{tabular}{|c|c|}
\hline Question & Student Responses \\
\hline $\begin{array}{l}\text { How do you think a highway bypass project } \\
\text { would (could) hurt the social landscape in the } \\
\text { community? }\end{array}$ & 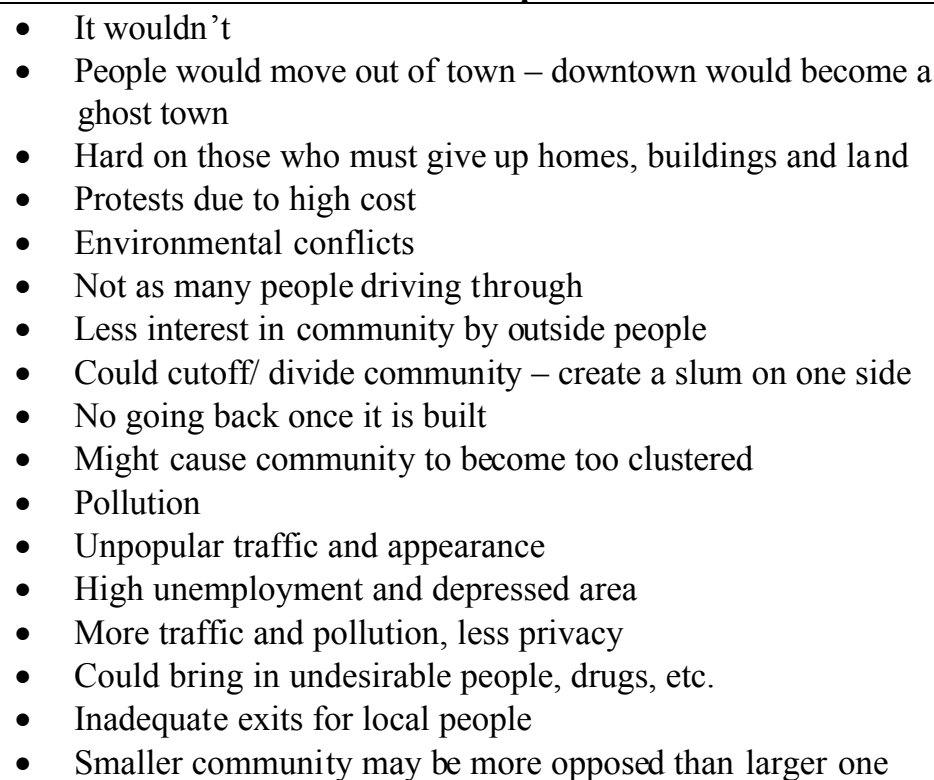 \\
\hline
\end{tabular}

All students seemed to easily identify the positive impacts both projects would have. About 16 percent of responses indicated no negative impacts of the dam project while only 4 percent of responses indicated negative impacts would not result from the highway by-pass project.

When identifying how a large dam could hurt the economy, many students considered the economic loss due to land use loss or mentioned the economic effect if the dam failed. A few identified the need to raise taxes to build it and the financial strain it might cause.

The social benefits identified for a large dam project included recreational opportunities, and a sense of pride for the area. The negative impacts of such a project included destruction of the natural environment, protests and debates and possibly a political nightmare. A few students also considered that it would benefit others away from the area by providing water and electricity, while not benefiting the local people to any great extent.

The second project students were asked to consider was a highway by-pass project in western Pennsylvania. Students were generally familiar with several highway projects in the area and had a fairly good understanding of the economic and social benefits, as they had been briefly discussed in another class. When discussing how such a project could hurt the economy students considered a number of possibilities. They considered the cost to build the road and its effect on taxes, the impact of less traffic through town on local businesses, and the fact that job growth may occur outside the area due to improved access away from the area.

In discussing how such a project could hurt the social landscape of the area, students pointed out a number of insightful observations. In addition to the increased traffic and environmental issues, several students noted the highway could create a dividing line through the community. They also noted that improved highway access could also result in more transient people passing through town and degrading the community. 


\section{Video}

After completing the survey and addressing the questions associated with the two projects, students watched the PBS Building Big video on Dams. ${ }^{9}$ The video begins by discussing the 1889 Johnstown Flood, with which many local students are already familiar. The video then presents interesting examples of how dams are related to the economic progress of growing nations, highlighting the Aswan High Dam in Egypt, Hoover Dam in the U.S. and Itaipu Dam between Brazil and Paraguay. The video discusses not only the benefits but also stresses the damage dams and the large lakes they create can have on the surrounding environment, people and their culture.

\section{Student Assignment}

The students then completed a two-part writing assignment. A copy of the assignment is in the Appendix B. Based on the video, students discussed the advantages and disadvantages of dams and how dams influence society and development. For the second half of the assignment students considered a real project of their choosing and discussed the social, economic, and environmental significance of the project within the local community, including both good and bad aspects.

Students were encouraged to discuss a project with which they were personally familiar from their hometown or their summer work experience. The author provided a selection of local projects, described in varying levels of detail, for student use. For some of the local projects, newspaper articles were included for student use. Of the 25 students in the class, 12 selected projects of their own choosing. The other 13 selected from the projects provided by the author. Of those students, 7 discussed the selected project in more detail than was provided by the author, suggesting that they were either familiar with the project themselves, or they did some research to learn more about the project. As with other writing assignments in the course, students had their essay peer-reviewed ${ }^{8}$ by a friend or classmate prior to final submission.

\section{Class Discussion}

A brief class discussion was used to highlight some of the social and economic impacts of various projects students selected. In the discussion, it was emphasized that people in different situations can have quite different perspectives on the positive and negative impacts of any given project.

\section{Student Feedback}

Students were asked to provide feedback on this assignment. Although students complained about the amount of writing in the course, a number of them noted that they thought this assignment was one of the most interesting and worthwhile assignments in the course. They generally enjoyed the Building Big Video and added that the essay was a nice change of pace from some other writing assignments. Several noted that this assignment got them thinking about things in a new way or in a way they had not thought before. One student noted they thought they understood the need and uses of dams, but really had never thought about the social impact of these projects. This assignment helped them realize that there really is a lot to consider in major civil engineering projects.

One of the frequent comments made by students was that they liked being able to select their own project for the assignment. They felt it allowed them to discuss something in which they had 
genuine interest. In addition, almost all of the essays were noticeably well written indicating that students took pride in their work and had likely made use of the peer-review process, as requested.

\section{Conclusions}

Engineering technology students should possess an appreciation of the social and economic impact of real-world engineering projects. A pre-assignment survey suggests that by their junior year, a number of students are aware that civil engineering projects influence society and the economy to some degree. To further develop their abilities in identifying and discussing these issues, students in an undergraduate civil engineering technology course watched an interesting video on dams and completed a subsequent writing assignment. In the writing assignment, students discussed the advantages and disadvantages of dams and how dams influence society and development. Students also selected a specific civil engineering project and discussed the social, economic, and environmental significance of the project within the local community, including both good and bad aspects. Many students took the opportunity to discuss projects of their own interest. This suggests this assignment gave them more of an opportunity to express their individual interests than other assignments in the course. Students generally liked the assignment and thought it was a worthwhile learning experience in the course.

\section{Bibliography}

1. Technology Accreditation Commission, ABET, "Criteria for Accrediting Engineering Technology Programs (2002-2003)" URL http://www.abet.org/images/Criteria/2002-03TACCriteria.pdf, accessed January 14, 2003.

2. Barger, M. and Hall, M.W. "Sustainability in Environmental Engineering Education." Proceedings, 1998 ASEE Annual Conference, June 1998.

3. Pritchard, M.S. and Tsang, E. "Service Learning: A positive Approach to Teaching Engineering Ethics and Social Impact of Technology.” Proceedings, 2002 ASEE Annual Conference, June 2000.

4. Okonkwo, C.U. and DeMendonca, M. "Integrating DFE as Core Course for Engineering Technology Programs." Proceedings, 2000 ASEE Annual Conference, June 2000.

5. Guensler, R., Chinowsky, P., and Conklin, C. "Development of a Web-Based Environmental Impact, Monitoring and Assessment Course." Proceedings, 1997 ASEE Annual Conference, June 1997.

6. Bilen, S., Devon, R.F., and Okudan, G. "Cumulative Knowledge and the Teaching of Engineering Design Processes." Proceedings, 2002 ASEE Annual Conference, June 2002.

7. Thompson, P.L. "Designing a Discipline-Specific Introductory Course for Freshmen.” Proceedings, 2002 ASEE Annual Conference, June 2002.

8. Rose, A.T. "Using the Peer Review Process to Implement Writing Assignments in an Engineering Technology Course.” Proceedings, 2001 ASEE Annual Conference, June, 2001.

9. Building Big Video on Dams, PBS Building Big Video Series, URL http://www.pbs.org/wgbh/buildingbig/dam/index.html, accessed January 10, 2003. 


\section{Appendix A - Initial Assessment Survey}

Do not write your name on this sheet.

Please complete the following survey to assess your awareness of the influence of civil engineering projects on society, communities and the economy.

1. I feel that I am generally aware of the impacts civil engineering projects have on society and the economy

$\begin{array}{lllll}1 & 2 & 3 & 4 & 5 \\ \text { Agree } & & & & \text { Disagree }\end{array}$

2. Most large civil engineering projects have little to no impact on society or a community

$\begin{array}{lllll}1 & 2 & 3 & 4 & 5 \\ \text { Agree } & & & & \text { Disagree }\end{array}$

3. Most large civil engineering projects have little to no impact on the economy beyond those employed in design and construction

$\begin{array}{lllll}1 & 2 & 3 & 4 & 5\end{array}$

Agree $\quad$ Disagree

For the two scenarios presented, briefly respond to the following questions

A large dam is to be constructed in rural area of a developing nation to create a large lake to provide water for irrigation and for generating electricity

4. How do you think such a dam would help the developing nation's economy?

5. How might such a project hurt the economy?

6. How do you think building this large project would benefit the social landscape of the developing nation?

7. How do you think building this large project would (could) hurt the social landscape of the developing nation?

A highway bypass project is proposed around a community in western PA

8. How do you think a highway bypass project would help the local economy?

9. How do you think a highway bypass project would hurt the local economy?

10. How do you think a highway bypass project would benefit the social landscape in the community?

11. How do you think a highway bypass project would (could) hurt the social landscape in the community?

Appendix B - Assignment

CET 1131 - Soils Engineering

October 28, 2002

Professor Rose

Social Implications of Civil Engineering Projects

Watch the "Building Big Video" on DAMS. Write a two to three page essay (DUE MONDAY, NOVEMBER 25) briefly addressing the following issues:

- The advantages and disadvantages of dams

- How dams influence society and development

In addition to the above, consider one of the scenarios described below, or choose a local civil engineering project that you are familiar with, either in the Johnstown area or near your hometown, and briefly discuss the effects of this project on the local community. This might include discussion of the social, economic and environmental

Proceedings of the 2003 American Society for Engineering Education Annual Conference \& Exposition Copyright $\odot$ 2003, American Society for Engineering Education 
significance of the project within the local community. Discuss both the good and bad impacts these projects might have.

- A large landfill in a small community in Somerset County employs 25 full-time employees and imports about $70 \%$ of its waste material from outside Pennsylvania. The landfill is not located directly off an interstate highway, but is accessible from state routes through the community. For each of the 580,000 tons of waste dumped at the landfill each year, the county receives $\$ 1.38$ from the landfill owner and the local township gets $\$ 1.59$. The landfill will be operated for approximately 30 years. (Two articles on Landfills are attached).

- $\quad$ The Route 56 west end by-pass in Johnstown (www.route56westend.com)

- $\quad$ AMD \& ART is working to improve the coal region of west central PA by cleaning up acid mine drainage (AMD) and developing community assets. The attached article and their web site: http://www.amdandart.org/ provide much additional information about their work and philosophy and can be utilized if you choose.

- A power plant in the Laurel Highlands that will burn coal mine waste (boney piles) from throughout Cambria, Somerset, Westmoreland and Indiana Counties

- A project to install sanitary sewer lines in a rural part of Westmoreland County is required by PA DEP to improve the water conditions in Loyalhanna Creek and its tributaries. Many homes in the community are close to 40 years old and are mostly owned by their original owners who are typically retired and on fixed incomes. Up to this point, each home had its own septic system (sand mound). A number of new homes nearby have been built in recent years and have strained the capacity of the ground to effectively treat household sewage before it reaches nearby streams. In addition, light in dustrial and commercial development on a nearby state highway can not occur without the sewer line. As a result, DEP is requiring the town extend a sewer line into this area and that all homes and businesses, new and old be tied into the new sewer line. State grants and low interest loans can be used to pay for the design and installation of the sewer line. Each homeowner has one-year to connect to the sewer line. The must use Sewer Authority approved contractors and the average cost is about $\$ 1500$ to complete and test the connection. In addition, each homeowner will now have to pay a sewage bill of approximately $\$ 15$ per month.

- $\quad$ PADOT is widening Route 219 to three lanes in each direction from Scalp Avenue to Galleria Drive. The widening will move the highway closer to some homes and businesses. The project requires replacement of the Oakridge Drive bridge (currently underway) and the Route 56 Expressway bridge over Route 219 in Richland Township near the Galleria shopping mall.

\section{ANDREW T. ROSE}

Andrew T. Rose is an Assistant Professor of Civil Engineering Technology at the University of Pittsburgh at Johnstown (UPJ) in Johnstown, Pennsylvania. Before joining the faculty at UPJ, he was a Staff Engineer with GAI Consultants in Pittsburgh. His teaching interests include soil mechanics, foundation design, structural steel design, structural analysis, and incorporating practical design experience into the undergraduate civil engineering technology curriculum. His research interests include soil behavior, behavior of laterally loaded transmission line structure foundations, and statistical calibration of foundation design models. Dr. Rose received B.S. and M.S. degrees in Civil Engineering from the University of Connecticut in 1985 and 1986 and a Ph.D. from Virgin ia Polytechnic Institute and State University in 1995. He is a licensed Professional Engineer in Pennsylvania. 